\title{
Boron Levels in Soils Cropped to Coffee and their Relationships to some Soil Properties in Ghana
}

\author{
A. A. Afrifa ${ }^{1}$, K. Ofori-Frimpong ${ }^{1 *}$ and M. K. Abekoe $^{2}$ \\ ${ }^{1}$ Cocoa Research Institute of Ghana, P. O Box 8, New Tafo-Akim, Ghana \\ ${ }^{2}$ Department of Soil Science, University of Ghana, Legon-Accra, Ghana \\ *Corresponding author
}

\begin{abstract}
Studies on boron levels in soils cropped to coffee were carried out in Ghana due to widespread reports on boron deficiency in soils of some coffee producing countries. Leaves and soils were sampled from Cocobod coffee plantations at Bogoso, Suhuma, Manso-Mim, Bunso and Bepong, which represent the main coffee growing areas in the Western, Ashanti and Eastern regions of Ghana. Also determined were percent $\mathrm{OC}$ and $\mathrm{Ca}, p \mathrm{H}$, texture and statistical relationships established for both leaf and soil boron contents and the soil properties. The results showed that available $\mathrm{B}$ in the $0-30 \mathrm{~cm}$ depth ranged from 0.77 to $1.54 \mathrm{mg} \mathrm{B} \mathrm{kg}^{-1}$ soil. Surface soil $\mathrm{pH}$ values ranged from 5.4 to 6.8 and the subsurface soil from 5.1 to 6.7. Leaf B was between 28.7 and $42.5 \mathrm{mg} \mathrm{B} \mathrm{kg}^{-1}$. The leaf $\mathrm{Ca} / \mathrm{B}$ ratio used as index of B deficiency was between 331.4 and 398.8; values high enough to suggest that boron was low compared to Ca concentrations in the leaves, a condition which implies that available B in the soils was below the levels required to support coffee plants. All locations of sampling indicated that there was positive correlation between percent OC, calcium and available B in the surface soils. Similarly, the relationship between percent clay, calcium and available B in the subsurface soils was positively correlated. Soil available B at $0-30 \mathrm{~cm}$ depth was highly influenced by percent $\mathrm{OC}$ and $p \mathrm{H}$. Coffee leaf $\mathrm{B}$ content and soil $p \mathrm{H}$ was negatively correlated at $p \mathrm{H}$ above 5.8, but was positive when the $p \mathrm{H}$ was below 5.8. Boron levels in the coffee leaves were within the critical range of $2-40 \mathrm{mg} \mathrm{B} \mathrm{kg}^{-1}$ although soil available B appeared low.
\end{abstract}

\section{Introduction}

Studies on boron levels in soils cropped to coffee were carried out in Ghana due to the widespread report on boron deficiency in soils of some coffee producing countries. Boron is an essential plant micronutrient which is important in cell division and is apparently a necessary component of the cell wall (Jackson \& Chapman, 1975; Cohen \& Lepper, 1977; Slack \& Whittington, 1964). Boron is known to be directly or indirectly involved in several enzyme activities and also for the stabilisation of positive electrostatic charge in plasma membrane that is generated by the actions of phytochrome and gravity (Tanada, 1978). It is essential for increasing the pollen producing capacity of anthers and pollen grain viability. Boron deficiency decreases the rate of water absorption, root growth and translocation of sugars in plants.

The main source of boron in soils is sedimentary and igneous rocks (Evans \& Sparks, 1983). However, it is known that soil boron content is enhanced by an increase in soil organic matter and a decrease in soil $p \mathrm{H}$. It is also influenced by the texture of the soil, with coarse textured soils having low boron content.

Information on the boron content of soils in West Africa and factors affecting its availability and uptake is lacking. The few available data indicate a range of $0.01-0.78 \mathrm{mg} \mathrm{B} \mathrm{kg}^{-1}$ soil for surface soils cropped to cocoa and coffee in Nigeria (Egbe \& Omotosho, 1972; Omotosho, 1977; Ojeniyi \& Egbe, 1984). The amount present in semi-deciduous soils is very low compared to the range of $0.2-2.0 \mathrm{mg} \mathrm{B} \mathrm{kg}^{-1}$ soil for humid regions (Jackson, 1958). Due to low levels of the element, widespread boron deficiency symptoms were observed in leaves and pods of high yielding Amazon cocoa varieties in Ghana and coffee in Nigeria (Asomaning \& Kwakwa, 1967; Omotosho, 1977). Values of $2-40 \mathrm{mg} \mathrm{B} \mathrm{kg}^{-1}$ in coffee leaves have been reported as the critical range below which boron deficiency symptoms are expected on the leaves (Chaverri et al., 1957; Culot et al., 1958; Loue, 1960). The concentration of B in coffee leaves is influenced by $\mathrm{Ca} / \mathrm{B}$ ratio in the plant. 
Perez et al. (1956) classified coffee leaves with $\mathrm{Ca} / \mathrm{B}$ ratio of $60-400$ as adequate for a normal growth of coffee plant. Boron concentration in coffee leaves is also known to be affected by soil $p \mathrm{H}$. Low $\mathrm{B}$ concentrations are observed when soil $p \mathrm{H}$ levels are greater than 6.3-6.5. Boron deficiency is known to be more widespread than any other micronutrients in many parts of the world where coffee is grown (Gupta, 1968), yet very little work has been carried out on this nutrient element in Ghana. Unlike cocoa, not much attention has been given to boron as a micronutrient in coffee plantations in the country. Therefore, the objective of this study is to report on the available B levels in some coffee growing soils in Western, Ashanti and Eastern regions of Ghana, and the soil properties that affect boron concentrations in the coffee plant.

Soil and coffee leaf sampling

\section{Materials and methods}

Soils from five coffee growing areas were sampled from Suhuma $\left(06^{\circ} 15^{\prime} \mathrm{N}, 02^{\circ} 28^{\prime} \mathrm{W}\right)$ and Bogoso (05 $\left.33^{\prime} \mathrm{N}, 02^{\circ} 10^{\prime} \mathrm{W}\right)$ in the Western Region, Manso-Mim (06 $\left.28^{\prime} \mathrm{N}, 01^{\circ} 58^{\prime} \mathrm{W}\right)$ Ashanti Region, Bepong $\left(06^{\circ} 40^{\prime} \mathrm{N}, 00^{\circ} 40^{\prime} \mathrm{W}\right.$ ) and Bunso (06 $20^{\prime} \mathrm{N}, 00^{\circ} 28^{\prime} \mathrm{W}$ ) in the Eastern Region. Surface $(0-15 \mathrm{~cm})$ and subsurface $(15-30 \mathrm{~cm})$ soils were sampled $1.0 \mathrm{~m}$ away from the base of each coffee plant on which the leaves were sampled. The soil samples were air-dried and sieved through a 2-mm mesh for analysis in the laboratory. Coffee leaves were sampled from either the second or third mature leaves from the apical bud of local Robusta coffee plants. The leaf samples were taken from at least 40 plants within the coffee plots, they were bulked and taken to represent the location. The leaves were washed, oven-dried at $80^{\circ} \mathrm{C}$ for $24 \mathrm{~h}$ and milled.

\section{Laboratory determinations}

Soil $p \mathrm{H}$ was determined on 1:2.5 soil to water ratio by glass electrode method. Other chemical analyses included organic carbon (Walkley \& Black, 1934), calcium was determined by using Atomic Absorption Spectrophotometer after extracting it with $1 M$ ammonium acetate ( $p \mathrm{H}$ 7.0). Soil B was extracted by the hot water method of Berger \& Troug (1944). Particle size distribution was determined by the Bouyoucos (1962) hydrometer method. All laboratory analyses were carried out on both surface and subsurface soils.

The milled coffee leaves were ashed and digested with a tenary mixture of perchloric, nitric and sulphuric acids. The boron content in both soil and coffee leaves were determined by the curcumin colourimetric method (Naftel, 1939) as modified by Dible et al. (1954). Calcium in the digest was determined by the method described by Jackson (1958). Sample correlation analysis was used to calculate the correlation coefficients among the various parameters determined.

\section{Physico-chemical properties of the soils}

\section{Results and discussion}

Table 1 shows the physical and chemical properties of the soils under study. The soils from the various locations vary in properties. At all five coffee growing areas studied, organic carbon content was greater in the surface soils than in the subsurface. The percent OC ranged from 1.68 to 3.06 for the surface soils, while that of the subsurface were from 0.75 to 2.05 . This may be attributed to large volume of litter collected on the soil surfaces. Soil $p \mathrm{H}$ was moderately acid and also higher in the surface soils than in the subsurface. The availability of boron is related to soil $p \mathrm{H}$ with the element being most available in acid soils. Thus, the moderately acid condition of the soils suggests that boron content of the soils would be inadequate for coffee plants. Calcium levels ranged from 3.7 to $14.8 \mathrm{mg} \mathrm{Ca} / 100 \mathrm{~g}$ for the surface soil and 1.4 to $9.0 \mathrm{mg} \mathrm{Ca} / 100 \mathrm{~g}$ for the subsurface. Clay and silt contents in the soils increased from the 0 to $15 \mathrm{~cm}$ to $15-30 \mathrm{~cm}$ depth but no clear trend was observed in the sand content. Thus, there had been a build-up of clay and silt in the subsurface. 
TABLE 1

Some physical and chemical properties of soils from five coffee growing areas

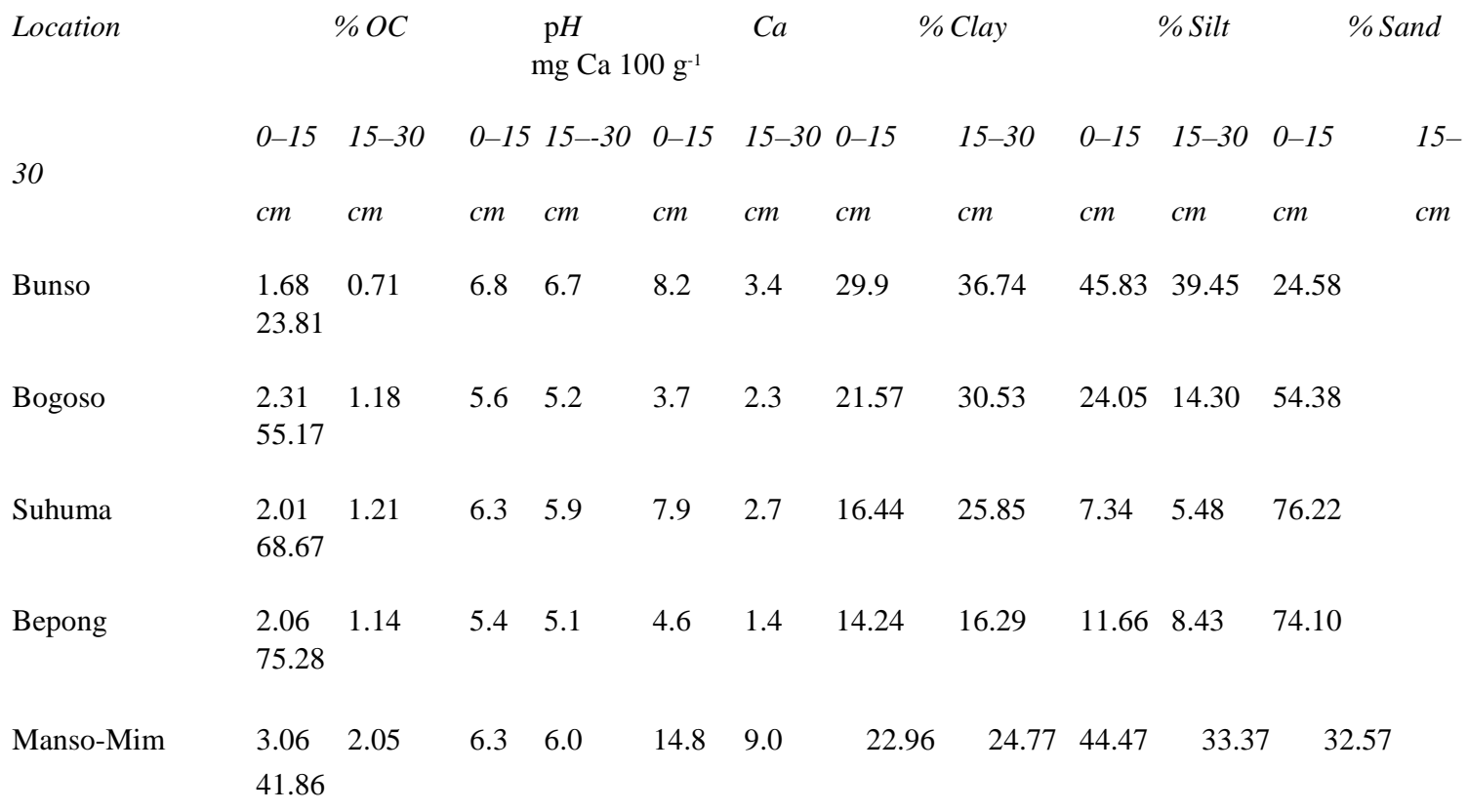

TABLE 2

Soil available boron, leaf boron and leaf $\mathrm{Ca} / \mathrm{B}$ ratios of coffee leaves

Available B

Location

Bunso

Bogoso

Suhuma

Bepong

Manso-Mim

\section{Available $B$}

$0-15 \mathrm{~cm} \quad 15-30 \mathrm{~cm}$

$0.62 \quad 0.41(1.03)$

$0.56 \quad 0.21(0.77)$

$0.48 \quad 0.37(0.85)$

$0.49 \quad 0.40(0.89)$

0.78

$0.76(1.54)$
Leaf B
$m g B g^{-1}$ soil

28.7

42.5

34.2

29.1

30.5
Leaf $\mathrm{Ca}$ mg Ca kg-1

12.87

9.38

9.69

12.27

12.46
Ca/B ratio

369.6

398.8

331.4

357.0

380.1

Values in bracket represent B concentrations in the 0-30 cm depth.

\section{Boron contents in soil and coffee leaves}

The available B levels in the soils from the various locations are shown in Table 2. Available B levels in the surface soils were higher than those in the subsurface. According to Reisenauer et al. (1973), soils may be roughly categorized on the basis of hot water soluble B into the following groups: (1) < $1.0 \mathrm{mg} \mathrm{B} \mathrm{kg}^{-1}$ - soils that may not supply sufficient B to support normal growth, (2) $1.0-5.0 \mathrm{mg} \mathrm{B} \mathrm{kg}{ }^{-1}$ - soils that supply concentrations of B that usually allow normal growth of plants, and (3) > $5.0 \mathrm{mg} \mathrm{B} \mathrm{kg}^{-1}$ - soils that may supply toxic concentra-tions of B. The available B content in Bunso and Manso-Mim soils within the 0-30 cm depth were 1.03 and $1.54 \mathrm{mg} \mathrm{B} \mathrm{kg}^{-1}$, respectively, and, thus, fell within the category of soils that may supply sufficient B to support normal growth of crops. The rest of the soils (Bogoso, Suhuma and Bepong) had less than $1.0 \mathrm{mg}$ $\mathrm{B} \mathrm{kg}^{-1}$ and were, therefore, deficient in B. 
All the soils had greater available B levels in the surface $(0-15 \mathrm{~cm})$ than in the $15-30 \mathrm{~cm}$ depth. This may be attributed to the accumulation of organic matter on the surface soil as shown by the Manso-Mim soil which had greater organic carbon content $(3.06 \%)$ than the other soils (Table 1). Variations in soil available B levels at the various coffee growing areas may be due to differences in other soil properties such as soil $p \mathrm{H}$ and texture (Hingston, 1964; Bingham, 1973). The low levels of available B in Bepong and Suhuma soils may be due to the hilly nature of the two areas, a terrain that encourages erosion and subsequent removal of organic matter from the soil surface. Due to the rocky nature of these two areas, the B element may be locked up in the rocks and render the nutrient unavailable to plants; a phenomenon which sharply contrasts B availability in decomposed organic matter or that adsorbed and precipitated on surfaces of soil particles (Russell, 1973; Bingham, 1973).

The boron levels in the coffee leaves are shown in Table 2. The values ranged from 28.7 to $42.5 \mathrm{mg} \mathrm{B} \mathrm{g}^{-1}$ leaf, with Bogoso having the highest followed by Suhuma, Manso-Mim, Bepong and Bunso in decreasing order. Among the factors that influence leaf $\mathrm{B}$ concentration is the $\mathrm{Ca} / \mathrm{B}$ ratio. Tissue $\mathrm{Ca} / \mathrm{B}$ ratio is often considered a reliable index for $\mathrm{B}$ deficiency or toxicity in plants. $\mathrm{The} \mathrm{Ca} / \mathrm{B}$ ratios for the coffee leaves ranged from 331.4 to 398.8 , the highest being Bogoso, and Suhuma, the lowest. The $\mathrm{Ca} / \mathrm{B}$ ratios fell within the range of $60-400$ for normal coffee leaves (Perez et al., 1956), but the values were, however, clustered at the upper percentile of the range. This is an indication of a low B concentration with respect to $\mathrm{Ca}$ in the leaves.

\section{Relationship between soil available B and some soil properties}

The effects of soil properties such as percent $\mathrm{OC}, p \mathrm{H}$, texture and $\mathrm{Ca}$ on levels of soil available $B$ were analysed and the correlation coefficients presented (Tables 3 and 4). Percent OC in the surface and subsurface soils positively and significantly correlated with available B in Bogoso and Suhuma $(p<0.01)$, whereas in the same soils available B correlated negatively with soil $p \mathrm{H}$.

TABLE 3

Correlation coefficients between soil available boron and some soil properties at different coffee growing areas

\begin{tabular}{|c|c|c|c|c|c|}
\hline \multirow[t]{2}{*}{ Soil properties } & \multicolumn{5}{|c|}{ Locations } \\
\hline & Bepong & Bogoso & Suhuma & Manso-Mim & Bunso \\
\hline$\% \mathrm{C}_{1}$ & 0.494 & $0.988 * *$ & $0.890 * *$ & 0.532 & 0.691 \\
\hline$\% \mathrm{C}_{2}$ & 0.167 & $0.989 * *$ & $0.891 * *$ & 0.238 & -0.302 \\
\hline$p \mathrm{H}_{1}$ & 0.573 & $-0.817 * *$ & $-0.948 * *$ & 0.049 & 0.503 \\
\hline$p \mathrm{H}_{2}$ & 0.404 & $-0.940 * *$ & 0.540 & 0.174 & 0.557 \\
\hline $\mathrm{Ca}_{1}$ & $0.748 * *$ & 0.019 & 0.410 & 0.324 & 0.694 \\
\hline $\mathrm{Ca}_{2}$ & 0.547 & 0.536 & $0.598 *$ & 0.220 & $0.710^{*}$ \\
\hline$\% \mathrm{Clay}_{1}$ & -0.018 & 0.320 & 0.425 & -0.512 & 0.410 \\
\hline$\% \mathrm{Clay}_{2}$ & -0.043 & 0.350 & 0.115 & 0.010 & 0.371 \\
\hline$\%$ Silt $_{1}$ & $0.650^{*}$ & 0.517 & 0.544 & -0.143 & -0.420 \\
\hline$\%$ Silt $_{2}$ & 0.319 & 0.132 & $0.685^{*}$ & -0.440 & -0.198 \\
\hline$\%$ Sand $_{1}$ & -0.490 & -0.585 & -0.663 & $0.696^{*}$ & $-0.799 *$ \\
\hline$\%$ Sand $_{2}$ & 0.070 & -0.532 & -0.206 & 0.440 & $0.816^{* *}$ \\
\hline
\end{tabular}

TABLE 4

Correlation coefficients between soil available boron and some soil properties at different coffee growing areas 


\begin{tabular}{|c|c|c|c|c|c|}
\hline & Bepong & Bogoso & Suhuma & Manso-Mim & Bunso \\
\hline$\% \mathrm{C}_{1}$ & 0.383 & $0.934 * *$ & $0.780 * *$ & -0.154 & -0.497 \\
\hline$\% \mathrm{C}_{2}$ & 0.412 & $0.923 * *$ & $0.782 * *$ & -0.202 & -0.318 \\
\hline$p \mathrm{H}_{1}$ & -0.129 & $-0.789 * *$ & -0.630 & 0.195 & 0.692 \\
\hline$p \mathrm{H}_{2}$ & -0.081 & $-0.890 * *$ & $0.660 *$ & 0.393 & $0.712^{*}$ \\
\hline $\mathrm{Ca}_{1}$ & 0.142 & 0.146 & 0.484 & 0.100 & 0.635 \\
\hline $\mathrm{Ca}_{2}$ & 0.229 & $0.625^{*}$ & 0.645 & 0.076 & 0.740 \\
\hline$\% \mathrm{Clay}_{1}$ & 0.607 & 0.522 & 0.435 & 0.051 & 0.374 \\
\hline$\% \mathrm{Clay}_{2}$ & 0.631 & 0.570 & 0.045 & 0.027 & 0.183 \\
\hline$\%$ Silt $_{1}$ & -0.576 & 0.382 & 0.125 & $0.622 *$ & -0.485 \\
\hline$\%$ Silt $_{2}$ & 0.403 & 0.078 & 0.061 & -0.487 & -0.247 \\
\hline$\%$ Sand $_{1}$ & -0.609 & $-0.759 *$ & -0.403 & 0.078 & $-0.887 * *$ \\
\hline$\%$ Sand $_{2}$ & 0.602 & $-0.669 * *$ & 0.075 & 0.256 & $0.835^{* *}$ \\
\hline
\end{tabular}

TABLE 5

Correlation coefficients between leaf $B$ and some soil properties, $C a / B$ ratio and calcium at different coffee growing areas

Leaf and soil

properties

$\begin{array}{cc}\text { Bepong } & \text { Bogoso } \\ -0.578 & -0.651^{*} \\ -0.468 & -0.661^{*} \\ 0.212 & 0.631^{*} \\ 0.370 & 0.704^{*} \\ -0.107 & 0.177 \\ 0.232 & -0.152 \\ -0.318 & -0.643 \\ -0.500 & -0.616 \\ -0.348 & -0.771^{*} \\ -0.097 & -0.808^{*} \\ 0.244 & -0.267 \\ -0.189 & -0.115 \\ 0.571 & 0.709 * \\ 0.110 & 0.831^{*} * \\ -0.031 & 0.696^{*} \\ -0.604 & 0.807^{*} *\end{array}$

Locations

$\% \mathrm{C}_{1}$

$\% \mathrm{C}_{2}$

$p \mathrm{H}_{1}$

$p \mathrm{H}_{2}$

$\mathrm{Ca}_{1}$

$\mathrm{Ca}_{2}$

B1

B2

$\%$ Clay $_{1}$

$\% \mathrm{Clay}_{2}$

$\%$ Silt $_{1}$

$\% \mathrm{Silt}_{2}$

$\%$ Sand $_{1}$

$\% \mathrm{Sand}_{2}$

Leaf Ca

$\mathrm{Ca} / \mathrm{B}$

$-0.604$

Location
Suhuma
$0.548^{*}$
$0.550^{*}$
$-0.691^{*}$
0.553
0.270
0.464
$0.751^{*}$
$0.583^{*}$
0.204
0.296
0.305
-0.022
-0.207
-0.260
$-0.917 * *$
$-0.928^{* *}$

$\begin{array}{cr}\text { Manso-Mim } & \text { Bunso } \\ & \\ 0.170 & 0.519 \\ -0.220 & 0.151 \\ 0.168 & -0.190 \\ -0.022 & -0.204 \\ -0.173 & 0.218 \\ -0.338 & -0.166 \\ -0.074 & 0.050 \\ -0.189 & -0.009 \\ -0.262 & 0.131 \\ 0.415 & 0.170 \\ 0.160 & 0.339 \\ 0.101 & 0.171 \\ 0.196 & 0.162 \\ 0.049 & 0.340 \\ 0.399 & -0.435 \\ -0.632 & -0.644\end{array}$

$*$ and $* *$ denote significant at $\mathrm{p}<0.05$ and 0.01 , respectively.

Subscript 1 means surface soil $(0-15 \mathrm{~cm})$.

Subscript 2 means subsoil $(15-30 \mathrm{~cm})$.

Considering the soil properties in isolation and their influence on soil available B levels, \%OC, $p \mathrm{H}, \%$ sand, \%silt and calcium, respectively, explained $85.2-97 \%, 62-88 \%, 44-57 \%, 42-47 \%$ and $35-41 \%$ of the availability of B in the soils. It may, therefore, be inferred that the levels of soil available $\mathrm{B}$ in the $0-15 \mathrm{~cm}$ were mostly affected by the organic matter content and $p \mathrm{H}$, with texture and calcium playing minor roles in enhancing B availability in the soils. This is in agreement with Okazaki \& Chao's (1968) report that organic matter is one of the main sources of $\mathrm{B}$ in acid soils. 


\section{Relationships between leaf boron and soil properties}

Table 5 shows the correlation coefficients between leaf boron and some soil properties. Leaf B and \%OC of the surface soils of Bepong and Bogoso were negatively correlated while those of Suhuma, Manso-Mim and Bunso showed positive correlations $(p<0.05)$. Correlation coefficient between leaf $\mathrm{B}$ and \%OC of the subsurface soils of Bepong, Bogoso and Manso-Mim were positive while those for Suhuma and Bunso were negative. Negative correlation was obtained between leaf $\mathrm{B}$ and soil available $\mathrm{B}$ at soil $p \mathrm{H}$ levels greater than 5.8.

From the correlation results reported, it was evident that in most cases where there were significant negative correlation coefficients for Bepong and Bogoso, significant positive correlation also existed for Suhuma and Bunso and vice versa. This is in conformity with the differences in the soil organic matter content and $p \mathrm{H}$ levels of the two soils. Manso-Mim, Bunso and Bogoso soils had $p \mathrm{H}$ above 5.8 while Suhuma and Bepong had $p \mathrm{H}$ below 5.8. Thus, the dominant soil factors that affect $\mathrm{B}$ availability in the coffee growing areas are soil organic matter and $p \mathrm{H}$.

\section{Conclusion}

Available boron levels in soils of the major coffee growing areas in Ghana may be categorized into two groups: Bunso and Manso-Mim (>1.0 $\mathrm{mg} \mathrm{B} \mathrm{kg}^{-1}$ ) and Bogoso, Bepong and Suhuma (< $\left.1.0 \mathrm{mg} \mathrm{kg}^{-1}\right)$. The amounts of boron in the coffee leaves were within the range for normal growth of coffee although soil available B concentrations appeared low in three of the soils. Organic matter content and $p \mathrm{H}$ of the soils greatly influenced the concentrations of $\mathrm{B}$ in the soils. Since creating acid conditions in soils for optimum growth of crops is not the norm, the options for increased coffee production in the country would be proper management of soil organic matter and application of $\mathrm{B}$ fertilizers to the coffee plantations.

\section{References}

Asomaning E. J. A. and Kwakwa R. S. (1967). Boron deficiency and pod malformations in cocoa (Theobroma cacao L.). Ghana J. Sci. 7:126-129.

Berger K. C. and Truog E. (1944). Boron test and determination for soils and plants. Soil Sci. 57:25-36.

Bingham F. T. (1973). Boron in cultivated soils and irrigation waters. In Trace elements in the environment. Advances in chemistry; Series 123. (E. L. Kothny, ed.), pp. 130-138. Am. Chem. Soc., Washington, D.C.

Bouyoucos G. J. (1962). Hydrometer method improved for making particle size analyses of soils. Agron. J. 54: 464465.

Cheverri G. R., Bornemisza E. S. and Chaves F. S. (1957). Resultados del ana'lisis follar del cafeto en Costa Rica. Stica, San Jose, Costa Rica Informa-cion Tecnica No. 3.

Cohen M. S. and Lepper R., Jr. (1977). Effect of boron on cell elongation and division in squash root. Pl. Physiol. 59: 884-887.

Culot J. P., Wambeke A. Van and Cruegaert J. (1958). Contribution a l'etude des deficiences minerales du cafeier d'Arabic au kivu. Publ. Inst. Nat. Etud. Agron. Congo Belge, Serv. Sci. 73, pp. 1-105.

Dible W. T., Truog E. and Berger K. C. (1954). Boron determination in soils and plants. Simplified curcumin Procedure. Anal. Chem. 26: 418-421.

Egbe N. E. and Omotoso (1972). Nutrient deficiencies of cacao in Nigeria. 4th Int. Covoa Res. Conf. St Augustine, Trinidad. pp. 153-158.

Evans C. M. and Sparks D. L (1983). Chemistry and mineralogy of boron in pure and mixed systems: A review. Commun. Soil Sci. Pl. Anal. 14: 827-846.

Gupta U. C. (1968). Relationship of total and hot water soluble B, and fixation of added B to properties of Podzol soils. Soil Sci. Soc. Am. Proc. 32: 45-48.

Hingston F. J. (1964). Reactions between boron and clays. Aust. J. Soil Res. 2: 83-95.

Jackson M. L. (1958). Soil Chemical Analysis. Printice Hall, Englewood Cliffs, New Jersey, New York. 498 pp.

Jackson J. F. and Chapman K. S. R. (1975). The role of boron in plants. In Trace Elements in Soil-Plant-Animal Systems. (D. J. D. Nicholas and A. R. Egan, ed), pp. 213-225. Academic Press, New York.

Loue A. (1960). Nouvelles observations sur les oligo-elements dans la nutrition du cafeier (coffee canephora pierre). Café, Cacao, The 4(3): 133-149. 
Naftel J. A. (1939). Colorimetric micro determination of B. Ind. Eng. Chem. Anal. II: 407-409.

Ojeniyi S. O. and Egbe N. E. (1984). Boron-potassium-nitrogen fertilizer experiment on Amozon cocoa in Nigeria: Effect of Boron on yield. Proc. of 9th Int. Cocoa Res. Conf. Lomé. Togo. pp. 189-192.

Okazaki E. and Chao T. T. (1968). Boron adsorption and desorption by some Hawaiian soils. Soil Sci. 105: $255-259$.

Omotoso T. I. (1977). Boron nutrition problems of cocoa in Nigeria. Proc. 5th International Cocoa Conference, Ibadan. pp. 312-315.

Perez V. M., Chaverri G. and Bornemisza E. (1956). Algunos aspectos del abnamiento del cafeto conboro y. Calcio en las condiciones de la neseta central de Costa Rica. Stica. San Jose, Costa Rica Informacion Tecnico No. 1.

Reisenauer H. M., Walsh L. M. and Hoeff R. G. (1973). Testing soils for sulphur, boron, molybdenum and chlorine. Chapter 12. In Soil Testing and Plant Analysis. (L.M. Walsh and J. D. Beaton, ed.). Soil Sci. Soc. Am. Inc. Madison, Wisconsin. USA.

Russel E. W. (1973). Soil conditions and plant growth, 10th edn. Longman Ltd., London. 849 pp..

Slack C. R. and Whittington W. J. (1964). The role of boron in plant growth. III. The effects of differentiation and deficiency on radicle metabolism. J. exp. Bot. 15: 495-514.

Tanada T. (1978). Boron: Key element in the actions of phytochrome and gravity. Planta 143: 109-111.

Walkley A. and Black I. A. (1934). An examination of the Degtjareff method for determination of organic matter and the proposed modification of the chronic acid titration method. Soil Sci. 37: 29-37. 